\title{
Pemanfaatan sistem rotary biological contactor menggunakan kultur Omphalina sp yang diimobilisasi pada tandan kosong kelapa sawit untuk absorbsi logam berat $\mathrm{Cu}^{2+}$ dan $\mathrm{Hg}^{2+}$
}

\begin{abstract}
Utilization of rotary biological contactor system using Omphalina sp immobilized on oil palm empty fruit
\end{abstract} bunch for absorption of heavy metals $\mathrm{Cu}^{2+}$ and $\mathrm{Hg}^{2+}$

\author{
Firda DIMAWARNITA*) \& TRI-PANJI
}

Pusat Penelitian Bioteknologi dan Bioindustri Indonesia, Jl Taman Kencana 1, Bogor 16128, Indonesia

Diterima tgl 10 Maret 2017 / disetujui tgl 3 Oktober 2017

\begin{abstract}
Heavy metals such as lead, chromium, cadmium, copper, mercury, and arsenic which are industrial by-products can have negative impact on the environment if they not managed properly. Biosorption is environmentally-friendly waste treatment method. The advantage of biosorption compared to other waste treatment method is ecotechnology, which means effective, cheaper than chemical treatment and environmentallyfriendly technology. Using the concept of bioremediation-based on microbial enhanced recovery of metals (MERM) allows the possibility of concentration process (bio-concentration) of metal content through the process of biosorption in microbial cells. The process of bioconcentration potentially to be applied on a commercial scale to increase the recovery of high-value commercial metals. This study aims to absorb $\mathrm{Cu}^{2+}$ and $\mathrm{Hg}^{2+}$ metals using Omphalina sp. cultured on empty fruit bunches (EFB) in rotary biological contactor $(R B C)$ systems. The principle of this technique is waste containing metals was contacted with white rot fungi (WRF) Omphalina sp. which is attached to the surface of the media inside a reactor and then the final waste concentration was analyzed. This analysis was using atomic absorption spectrometry (AAS) device to measure the concentration of $\mathrm{Cu}^{2+}$ and $\mathrm{Hg}^{2+}$ metal ions and Freundlich isothermic equations for calculating maximum absorption power ( $q$ max). The highest absorption of $\mathrm{Cu}^{2+}$ ion is $0.3304 \mathrm{mg} / \mathrm{g}$ and $\mathrm{Hg}^{2+}$ is $0.074 \mathrm{mg} / \mathrm{g}$ for 6 hours. The adsorption capacity of Omphalina sp. for $\mathrm{Cu}^{2}+$ and $\mathrm{Hg}^{2}+$ solutions based on the Freundlich adsorption equation with maximum adsorption power for $\mathrm{Cu}^{2+}$ is $71.911 \mathrm{mg} / \mathrm{g}$ and $\mathrm{Hg}^{2+}$ is $20.216 \mathrm{mg} / \mathrm{g}$. Biosorbent Omphalina $\mathrm{sp}$. can be reused in biosorption process with percentage decrease of $\mathrm{Cu}^{2+}$ is $4.30 \%$ (4.3 ppm) and $\mathrm{Hg}^{2+}$ is $27.80 \%$ (1.39 ppm) for 18 hours.
\end{abstract}

[Key words : biosorption technique, empty fruit bunches, immobilization, rotary biological contactor, white rot fungi-Omphalina sp.]

\begin{abstract}
Abstrak
Logam berat seperti timbal, krom, cadmium, tembaga, merkuri, dan arsen yang merupakan hasil samping industri dapat berdampak negatif terhadap lingkungan jika tidak dikelola dengan baik. Biosorpsi merupakan metode pengolahan limbah yang ramah lingkungan. Keunggulan biosorpsi dibandingkan dengan metode pengolahan limbah yang lainnya adalah ekoteknologi yaitu teknologi efektif, murah dan ramah lingkungan. Melalui konsep bioremediasi berbasis microbial enhanced recovery of metals (MERM) memungkinkan terjadinya proses pemekatan (bio-konsentrasi) kandungan logam melalui proses biosorpsi dalam sel mikroba. Proses bio-konsentrasi tersebut berpeluang untuk diterapkan dalam skala komersial untuk meningkatkan recovery logam bernilai komersial tinggi. Penelitian ini bertujuan untuk mengabsorpsi logam $\mathrm{Cu}^{2+}$ dan $\mathrm{Hg}^{2+}$ menggunakan kultur Omphalina sp. pada media TKKS dalam sistem rotary biological contactor (RBC). Prinsip teknik ini yaitu limbah yang mengandung logam dikontakkan dengan kultur JPP Omphalina sp. yang melekat pada permukaan media di dalam suatu reaktor kemudian konsentrasi limbah akhir dianalisis kandungannya. Analisis ini menggunakan alat spektrometri serapan atom (SSA) untuk mengukur konsentrasiion logam $\mathrm{Cu}^{2+}$ dan $\mathrm{Hg}^{2+}$ dan persamaan isoterm Freundlich untuk menghitung daya absorbsi maksimum (q max). Penyerapan tertinggi ion $\mathrm{Cu}^{2+}$ sebesar $0,330 \mathrm{mg} / \mathrm{g}$ dan $\mathrm{Hg}^{2+}$ sebesar $0,074 \mathrm{mg} / \mathrm{g}$ selama 6 jam. Kapasitas adsorpsi Omphalina sp. terhadap larutan $\mathrm{Cu}^{2+}$ dan $\mathrm{Hg}^{2+}$ berdasarkan persamaan adsorpsi Freundlich dengan daya adsorpsi maksimumnya untuk $\mathrm{Cu}^{2+}$ sebesar $71,911 \mathrm{mg} / \mathrm{g}$ dan untuk $\mathrm{Hg}^{2+}$ sebesar 20,216 mg/g. Biosorben Omphalina sp. dapat digunakan ulang dalam proses biosorpsi dengan persentase penurunan $\mathrm{Cu}^{2+}$ sebesar 4,30\% (4,3 ppm) dan $\mathrm{Hg}^{2+}$ sebesar $27,80 \%$ (1,39 ppm) dalam waktu 18 jam.
\end{abstract}

[Kata kunci : imobilisasi, jamur pelapuk putih Omphalina sp, rotary biological contactor, teknik biosorpsi logam, tandan kosong kelapa sawit.] 


\section{Pendahuluan}

Pencemaran logam berat seperti timbal, krom, cadmium, tembaga, merkuri, dan arsen yang dihasilkan limbah industri sangat merugikan manusia dan lingkungan (Chergui et al., 2007). Logam berat yang terakumulasi dalam tubuh manusia akan menyebabkan berbagai macam penyakit serius seperti gangguan syaraf otak, ginjal akut, kelainan janin, bahkan dapat menyebabkan kematian (Mawardi, 2007). Namun, tak bisa dipungkiri bahwa perkembangan teknologi dan industri yang semakin pesat telah meningkatkan cemaran logam berat di lingkungan yang berasal dari tambang mineral, pestisida, toxic xenobiotics, metal, metalloid, halogenasi dan polisiklik aromatik hidrokarbon (Milovanović, 2014).

Upaya untuk mengurangi konsentrasi logam berat dalam limbah telah banyak dilakukan antara lain dengan cara presipitasi kimia, koagulasi, membran filtrasi, reverse osmosis, pertukaran ion, dan absorpsi (Das, 2005). Biosorpsi merupakan proses absorpsi menggunakan mikroorganisme seperti algae, fungi, dan bakteri sebagai agen sorpsi untuk menghilangkan dan recovery logam berat terkandung dalam limbah cair (Ahluwalia \& Goyal, 2007; Das et al., 2008). Keunggulan biosorpsi dibandingkan dengan metode lainnya adalah metode ini lebih efektif, murah, dan ramah lingkungan (Busuioc \& Carmen, 2013). Teknik bioremediasi berbasis microbial enhanced recovery of metals (MERM) memungkinkan terjadinya proses pemekatan (bio-konsentrasi) kandungan logam melalui proses biosorbsi dalam sel mikroba. Proses bio-konsentrasi tersebut berpeluang untuk diterapkan dalam skala komersial untuk meningkatkan pengambilan (recovery) logam berkonsentrasi kecil namun bernilai ekonomi tinggi.

Teknik biosorpsi logam berat yang mencemari tanah dengan agen biosorpsi dari jamur pernah dilakukan oleh Garcia et al. (2005), sedangkan biosorpsi logam berat dalam sludge dengan jamur dilaporkan oleh Fu \& Wang (2011). Penelitian lain mempelajari tentang berbagai jenis jamur yang dapat tumbuh pada kandungan logam berat dengan konsentrasi tinggi dilaporkan oleh Svoboda et al. (2000). Kultur jamur pelapuk putih (JPP) Omphalina sp. sebagai agen sorpsi yang ditumbuhkan pada tandan kosong kelapa sawit (TKKS), dalam penelitian sebelumnya diketahui mampu menyerap logam berat $\mathrm{Cu}^{2+}$ sebesar $70 \%$ dan $\mathrm{Hg}^{2+}$ sebesar 90\% (Dimawarnita et al., 2015). Omphalina sp. ditumbuhkan pada TKKS untuk meningkatkan stabilitas dan viabilitas sel. Menurut Brodelius (1987), imobilisasi akan membuat sel, organel atau enzim yang dapat digunakan mikroba untuk biokonsentrasi bekerja secara terus menerus. Omphalina sp. menghasilkan enzim lignolitik ekstraseluler yaitu mangan peroksidase (Mn-P), lignin peroksidase (Li-P), dan lakase yang mampu mendegradasi lignin menjadi $\mathrm{CO}_{2}$ dan $\mathrm{H}_{2} \mathrm{O}$
(Dimawarnita et al., 2015; Muslimah \& Kuswytasari, 2013). Lakase bersama lignin peroksidase berperan penting dalam proses perombakan lignin namun dalam perkembangannya juga berperan dalam degradasi senyawa xenobiotik seperti aromatik polisiklik dan senyawa fenolik (Lim'on-Pacheco \& Gonsebatt, 2009).

Penelitian lanjut penggunaan Omphalina sp. untuk biosorpsi logam berat adalah mengembangkan teknik aplikasinya untuk memudahkan dalam penerapannya di lapang pada masa yang akan datang. Teknik aplikasi biosorpsi logam berat pada limbah cair dapat dilakukan antara lain dengan teknik feed-batch, batch, packed-batch, dan rotary biological contactor (RBC). Teknik RBC pada prinsipnya adalah teknik penurunan kandungan logam berat oleh agen mikroba imobil yang ditempatkan dalam keranjang silinder yang berputar pada porosnya dalam suatu bak reaktor berisi cairan limbah. Kontak antara mikroba imobil dalam tabung silinder berputar dengan limbah akan terjadi aerasi dan sekaligus penyerapan logam berat secara kontinu. Penelitian ini bertujuan mengetahui kemampuan kultur Omphalina sp. dalam TKKS untuk biosorpsi logam $\mathrm{Cu}^{2+}$ dan $\mathrm{Hg}^{2+}$ yang diaplikasikan dengan teknik RBC.

\section{Bahan dan Metode}

\section{Kultur Omphalina sp.}

Omphalina sp. yang digunakan merupakan koleksi PPBBI dan dipelihara dalam PDA miring. Untuk mempersiapkan inokulum, Omphalina sp. mula-mula ditumbuhkan dalam cawan Petri berisi media PDA dan diinkubasikan pada suhu ruang $27-30{ }^{0} \mathrm{C}$ selama 2 minggu. Miselium Omphalina sp. kemudian dipindahkan ke media beras (40 g) dan diinkubasi pada suhu yang sama selama 1420 hari hingga seluruh permukaaan media beras terkolonisasi miselium. Miselium dalam media beras tersebut selanjutnya digunakan sebagai sumber inokulum. Inokulum (10 g) ditumbuhkan pada biomassa TKKS (200 g) yang telah dicuci dan dipotong halus dengan ukuran $5 \mathrm{~cm}$ dan disterilkan pada suhu $121^{\circ} \mathrm{C}$ selama 15 menit. Kultur ditumbuhkan pada suhu ruang $27-30^{\circ} \mathrm{C}$ selama 4 minggu. Miselium Omphalina sp. akan tumbuh dan terikat kuat pada permukaan seratserat dan mikro fibril TKKS membentuk jalinan yang tidak mudah tercuci (wash out) oleh aliran larutan. Kultur Omphalina sp. akan mempermudah penyerapan nutrisi dan ion logam.

\section{Teknik RBC}

Teknik RBC dilakukan dengan alat berupa keranjang plastik berbentuk silinder dengan diameter $15 \mathrm{~cm}$, tinggi $25 \mathrm{~cm}$ yang permukaannya dilengkapi dengan baling-baling yang dapat diputar pada porosnya. Keranjang silinder tersebut diisi dengan formula kultur Omphalina sp. sebanyak $10 \mathrm{~g}$ dan ditempatkan dalam suatu bak reakor berkapasitas 10L (Gambar 1). Larutan 
logam dialirkan dengan pompa pada permukaan baling-baling sehingga keranjang berisi formula kultur Omphalina sp. akan berputar dengan kecepatan 100 putaran/menit. Larutan $\mathrm{Cu}^{2+}$ dan $\mathrm{Hg}^{2+}$ sebagai limbah sintetik masing-masing diatur dengan konsentrasi awal $100 \mathrm{mg} / \mathrm{L}$ untuk logam $\mathrm{Cu}^{2}+$ dan 5 ppm untuk logam $\mathrm{Hg}^{2+}$ diatur pada $\mathrm{pH}$ 4. Analisa kandungan logam berat $\mathrm{Cu}^{2+}$ dan $\mathrm{Hg}^{2+}$ sebelum dan selama biosorpsi diamati pada alat RBC tersebut pada jam ke 1, 2, 4, 6, 8, dan 10 menggunakan spektrofotometer serapan atom (SSA) Penurunan kandungan logam dihitung dengan rumus sebagai berikut:

$$
\alpha \mathrm{s}=(1-\mathrm{Cs} / \mathrm{Co}) \times 100 \%
$$

$\alpha \mathrm{S}=$ persentase penurunan logam

$\mathrm{Cs}=$ konsentrasi akhir logam $(\mathrm{mg} / \mathrm{l})$

$\mathrm{Co}=$ konsentrasi awal logam $(\mathrm{mg} / \mathrm{l})$

Serapan logam dalam biosorben dihitung dengan rumus:

$$
\mathrm{q}=\mathrm{V}(\mathrm{Co}-\mathrm{Cs}) / \mathrm{m}
$$

$\mathrm{q}=$ serapan logam dalam JPP amobil atau biosorben ( $\mathrm{mg}$ logam/g biosorben)

$\mathrm{V}=$ volume larutan yang diperlakukan $(\mathrm{ml})$

$\mathrm{Cs}=$ konsentrasi akhir logam $(\mathrm{mg} / \mathrm{l})$

$\mathrm{Co}=$ konsentrasi awal logam $(\mathrm{mg} / \mathrm{l})$

$\mathrm{m}=$ berat biosorben kering $(\mathrm{mg})$

\section{Perhitungan absorpsi zat terlarut}

Absorpsi zat terlarut pada padatan sorben dilakukan berdasarkan persamaan isoterm sorpsi menurut Freundlich sebagai berikut:

$$
\begin{aligned}
& \frac{X_{m}}{m}=k \cdot C^{\frac{1}{n}} \\
& \log \left(\frac{X_{m}}{m}\right)=\log k+\frac{1}{n} \log C
\end{aligned}
$$

makna simbol:

$$
\begin{aligned}
\mathrm{X}_{\mathrm{m}}= & \begin{array}{l}
\text { serapan logam dalam biosorben } \\
(\mathrm{mg} / \text { gram sorben })
\end{array} \\
\mathrm{m}= & \text { berat sorben }(\text { gram }) \\
\mathrm{C}= & \text { konsentrasi zat }(\mathrm{mg} / \mathrm{liter}) \\
\mathrm{k}= & \text { kapasitas serapan maksimum } \\
& \text { (mg/gram sorben) } \\
\mathrm{n}= & \text { konstanta Freundlich }
\end{aligned}
$$

Nilai $\mathrm{k}$ dan $\mathrm{n}$ adalah konstanta sorpsi yang nilainya bergantung pada jenis sorben dan suhu absorpsi. Bila dibuat kurva $\log (\mathrm{Xm} / \mathrm{m})$ terhadap $\log \mathrm{C}$ akan diperoleh persamaan linear dengan intersep $\log \mathrm{k}$ dan kemiringan $1 / \mathrm{n}$, sehingga nilai $\mathrm{k}$ dan $\mathrm{n}$ dapat dihitung.

\section{Hasil dan Pembahasan}

\section{Preparasi Biosorben}

Jamur Omphalina sp. yang digunakan sebagai biosorben dalam penelitian ini merupakan koleksi isolat jamur pelapuk putih dari Pusat Penelitian Bioteknologi dan Bioindustri, Bogor.

Kultur murni Omphalina sp. dari media agar miring, terlebih dahulu dipreparasi untuk mendapatkan isolat unggul untuk kemudian diimobilisasi pada tandan kosong kelapa sawit. Kultur murni Omphalina sp. diremajakan dalam media Potato Dextrose Agar (PDA) (Gambar 2) selama 5 hari masa inkubasi pada suhu ruang $\left(27^{\circ} \mathrm{C}\right)$. Isolat Omphalina sp. secara makrokospis memiliki ciri- ciri pada permukaan miselium berwarna putih bersih, berserat seperti kapas, dan tidak menggumpal. Isolat inilah yang nantinya akan diimobilisasi pada TKKS dan mengabsorpsi logam $\mathrm{Cu}^{2+}$ dan $\mathrm{Hg}^{2+}$.

\section{Imobilisasi Omphalina sp. dengan Tandan} Kosong Kelapa Sawit

Proses imobilisasi Omphalina sp. Dengan TKKS bertujuan untuk menyangga jamur dan memadatkannya dalam sebuah zat pendukung inert. Omphalina sp. diinokulasi bersama TKKS dan dedak padi dengan konsentrasi $10 \%$ yang berfungsi juga sebagai media dan suplai nutrien selama proses imobilisasi berlangsung dalam plastik tahan panas (baglog). Baglog dibiarkan untuk pembiakan selanjutnya sampai terbentuk lapisa dari Omphalina sp. yang terlihat jelas pada permukaan zat pendukung (Gambar 3).

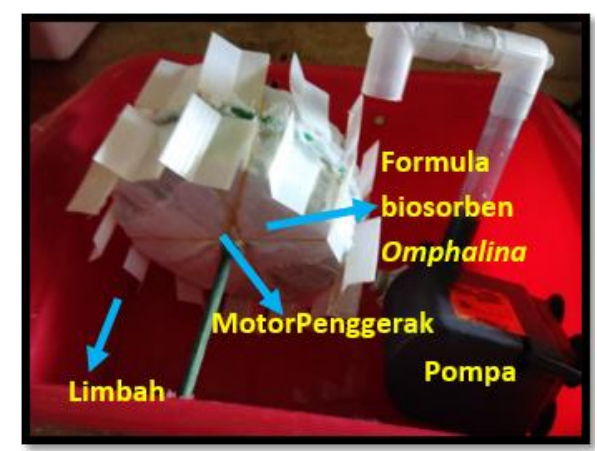

Gambar 1. Sistem aplikasi kultur Omphalina sp. dalam media TKKS dengan alat rotary biological contactor $(R B C)$

Figure 1. Application system of Omphalina sp. cultured in EFB of oil palm media with rotary biological contactor $(R B C)$

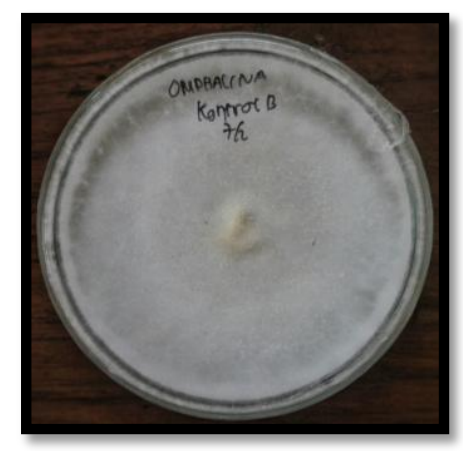

Gambar 2. Miselium Omphalina sp. pada media Potato Dextrose Agar.

Figure 2. The miselium of Omphalina sp. in Potato Dextrose Agar. 
TKKS memiliki struktur lignin yang kuat, sehingga kemampuan isolat Omphalina sp. unggul sangat diperlukan untuk mempertahankan pertumbuhan jamur selama proses imobilisasi. Lignin pada TKKS akan diurai oleh enzim lignolitik Omphalina sp. menjadi senyawa sederhana untuk mendapatkan suplai karbon yang diperlukan bagi jamur sebagai sumber energi dalam proses pertumbuhan. Proses imobilisasi berlangsung dalam plastik tahan panas yang telah disterilisasi (baglog), hal ini bertujuan untuk mencegah kontaminasi mikroorganisme yang memperlambat proses. Baglog kemudian diinkubasi dalam suhu ruang hangat $\left(30^{\circ} \mathrm{C}\right)$, hal ini dilakukan untuk mengembalikan faktor pertumbuhan jamur yang disesuaikan terhadap keadaan habitat jamur pelapuk putih di lingkungan bebas.

\section{Mekanisme biosorpsi ion-ion logam}

Proses biosorpsi ion $\mathrm{Cu}^{2+}$ menggunakan Omphalina sp. merupakan proses penyerapan yang bersifat aktif untuk kepentingan metabolisme sel dan pasif yaitu terserap pada dinding sel miselium jamur (Patil \& Kulkarni, 2016). Sedangkan, biosorpsi ion logam $\mathrm{Hg}^{2+}$ cenderung penyerapannya bersifat pasif karena ion $\mathrm{Hg}^{2+}$ bukan merupakan sumber mineral bagi metabolisme jamur secara umum dan tidak merupakan kofaktor enzim tertentu. Ion logam akan diserap ke dalam membran sel yang bergantung pada aktivitas metabolisme sel dan penyerapan intraseluler. Penyerapan ion logam pada permukaan sel terjadi karena adanya interaksi antara ion logam dengan gugus fungsi, seperti karbohidrat, hidroksi, sulfat, fosfat, dan amino yang terjadi melalui pertukaran ion dan adsorpsi secara fisik. Pertukaran ion juga merupakan salah satu cara yang digunakan oleh jamur untuk dapat menyerap logam, sehingga terjadi penyerapan yang cepat pada periode

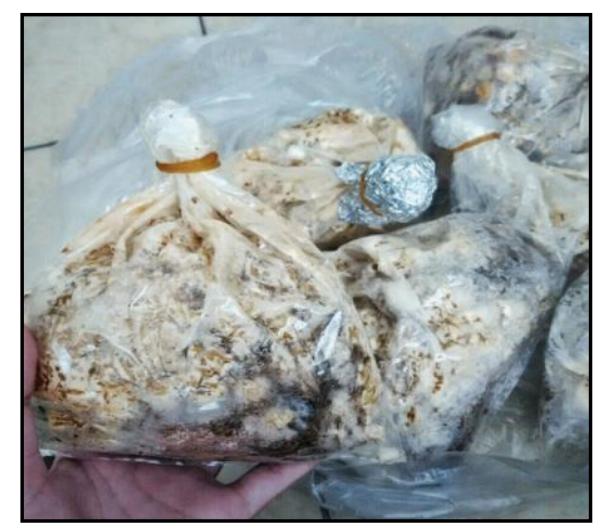

Gambar 3. Media Omphalina sp. pada Baglog TKKS

Figure 3. The medium of Omphalina $s p$. in Baglog TKKS. pertama. Proses ini terjadi karena adanya pertukaran ion-ion mono ataupun divalen pada dinding sel jamur seperti $\mathrm{Na}, \mathrm{Mg}$, dan $\mathrm{Ca}$, digantikan oleh ion-ion logam berat (Dimawarnita et al, 2015). Mekanisme pertukaran ion dapat dilihat pada Gambar 4.

Alat yang digunakan untuk mempermudah proses biosorpsi logam adalah alat RBC. Cairan limbah yang dipompa menyebabkan rotary berputar dan cairan limbah logam melewati formula yang berisi Omphalina sp. yang mengakibatkan terjadinya penyerapan logam. Perputaran dari formula menyebabkan adanya aerasi pada formula tersebut hingga dapat memperluas bidang penyerapan.

Hasil penelitian menunjukkan bahwa kultur Omphalina sp. efektif untuk penyerapan ion logam $\mathrm{Cu}^{2+}$ yang dapat dilihat dari penurunan konsentrasi kadar ion logam $\mathrm{Cu}^{2+}(\mathrm{Gambar} 5)$. Penurunan ion logam $\mathrm{Cu}^{2+}$ berlangsung dengan cepat sampai dengan waktu kontak 4 jam kemudian sedikit menurun pada waktu kontak 6 jam. Penurunan terbesar terjadi pada jam ke-6 yaitu konsentrasi penurunan kandungan ion logam $\mathrm{Cu}^{2+}$ mencapai 83,48 ppm dengan penyerapan pada biosorben 0,3304 mg/L (Gambar 6). Melekatnya Omphalina sp. pada permukaan media yang berputar akan menyerap logam-logam berat dalam larutan serta mengambil oksigen terlarut dalam air dan dari udara untuk proses metabolismenya, sehingga kandungan ion logam berat dalam larutan akan berkurang. Pertukaran ion juga merupakan salah satu cara yang digunakan oleh jamur untuk dapat menyerap logam, sehingga terjadi penyerapan yang cepat pada periode pertama. Proses ini terjadi karena adanya pertukaran ion-ion mono ataupun divalen pada dinding sel jamur seperti $\mathrm{Na}, \mathrm{Mg}$, dan $\mathrm{Ca}$, digantikan oleh ion-ion logam berat (Dimawarnita et al, 2015).

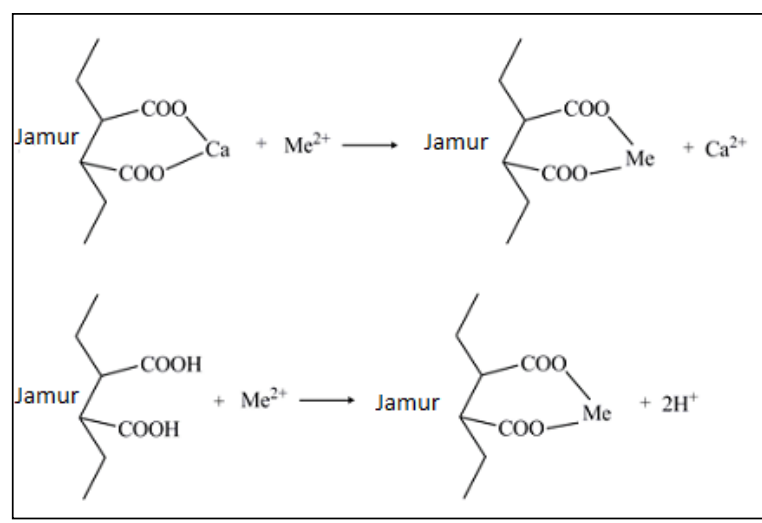

Gambar 4. Mekanisme pertukaran ion pada jamur (Wesenberg et al., 2003)

Figure 4. The mechanism of ion exchange in the fungi (Wesenberg et al., 2003). 
Semakin lama waktu kontak hingga jam ke-6 maka semakin naik jumlah ion $\mathrm{Cu}^{2+}$ yang terserap pada biosorben namun waktu perpanjangan waktu kontak menyebabkan penyerapan berikutnya relatif menurun. Hal ini disebabkan biosorben sudah mulai jenuh dan titik optimal penyerapan terjadi pada waktu 6 jam. Permukaan biosorben yang sudah mulai jenuh dan tertutup partikel logam berat akan menghambat proses biosorpsi pada waktu berikutnya.

Pola absorpsi $\mathrm{Hg}$ berlangsung mirip dengan penyerapan $\mathrm{Cu}$. Semakin lama waktu kontak maka semakin menurun kandungan ion logam $\mathrm{Hg}^{2+}$. Penurunan konsentrasi ion $\mathrm{Hg}$ tertinggi terjadi pada waktu kontak 6 jam. Konsentrasi ion logam turun dengan cepat sejalan dengan penambahan waktu. Pada waktu 6 jam konsentrasi ion logam $\mathrm{Hg}^{2+}$ mencapai $1,32 \mathrm{ppm}$ dan serapan ion logam $\mathrm{Hg}^{2+}$ dalam biosorben mencapai 0,074 $\mathrm{mg} / \mathrm{g}$ (Gambar 7) sedangkan pada jam berikutnya persentase penyerapan menurun dikarenakan terjadinya kejenuhan pada Omphalina sp. Berdasarkan hasil percobaan tersebut maka dapat disimpulkan bahwa waktu maksimal penyerapan ion logam $\mathrm{Hg}^{2+}$ yaitu pada waktu kontak 6 jam (Gambar 7 dan 8).

Serapan ion logam $\mathrm{Cu}^{2+}$ dan $\mathrm{Hg}^{2+}$ pada teknik RBC optimum pada waktu kontak jam ke 6 . Persentase penurunan logam $\mathrm{Cu}^{2+}$ tertinggi sebanyak $14 \%$ dan untuk logam $\mathrm{Hg}^{2+}$ sebanyak
85\% (Gambar 8). Hal ini menunjukkan bahwa Omphalina sp. efektif digunakan untuk biosorpsi logam berat baik $\mathrm{Cu}^{2+}$ maupun $\mathrm{Hg}^{2+}$. Persentase penurunan pada $\mathrm{Hg}$ lebih besar karena konsentrasi $\mathrm{Hg}^{2+}$ lebih rendah dibandingkan dengan konsentrasi $\mathrm{Cu}^{2+}$ sehingga daya sorpsi Omphalina sp. juga cepat.

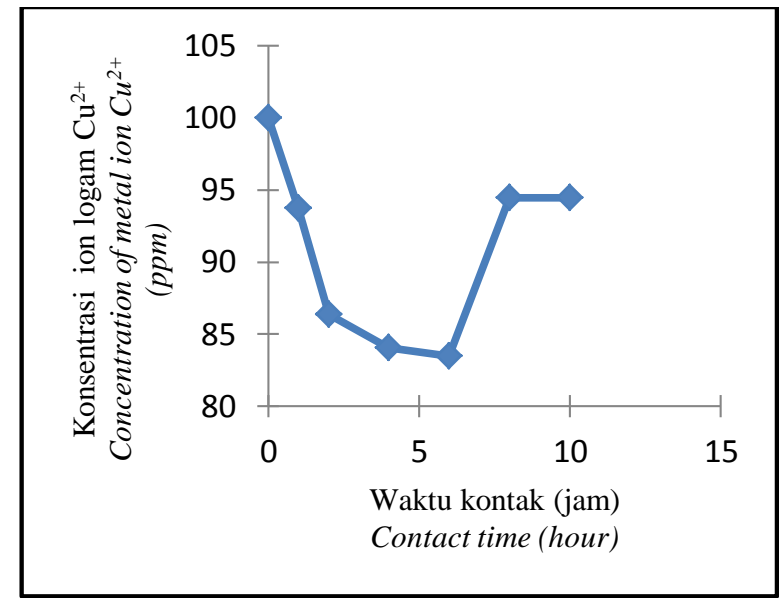

Gambar 5. Konsentrasi ion logam $\mathrm{Cu}^{2+}$ pada TKKS dengan kultur Omphalina sp. menggunakan teknik RBC

Figure 5. Concentration metal ion $\mathrm{Cu}^{2+}$ on EFB with Omphalina sp. immobilized using $R B C$ System

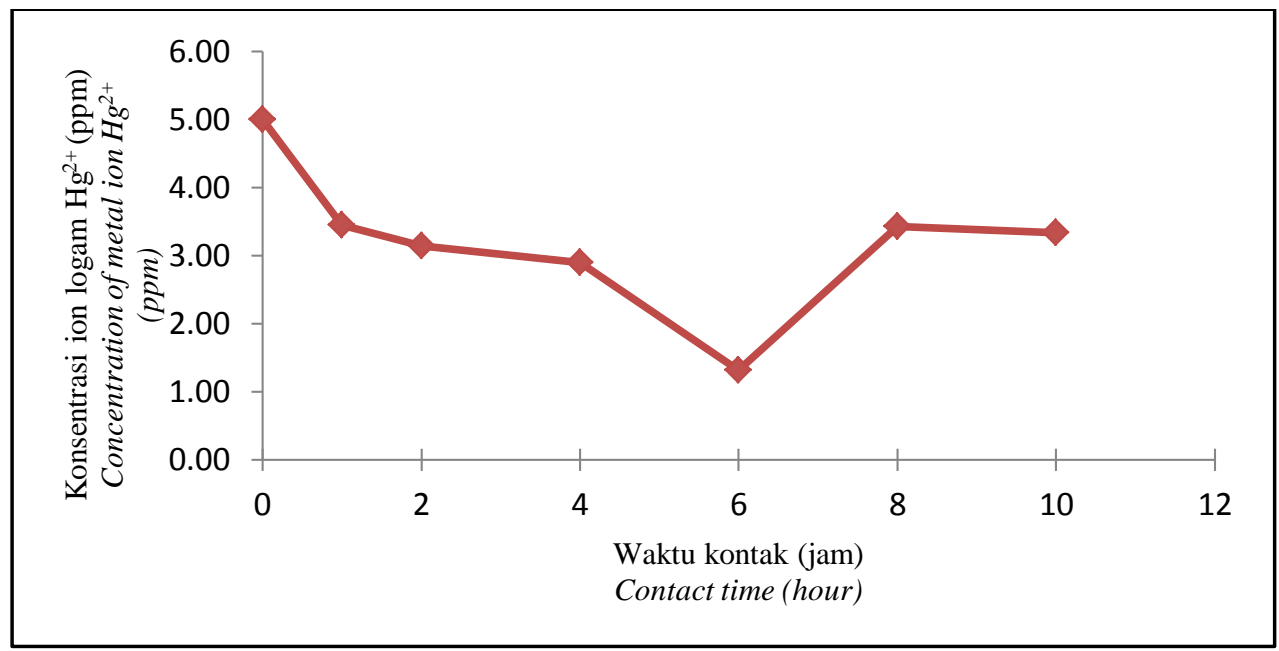

Gambar 6. Konsentrasi ion logam $\mathrm{Hg}^{2+}$ pada TKKS dengan kultur Omphalina sp. Pada TKKS dengan teknik RBC

Figure 6. Concentration metal ion $\mathrm{Hg}^{2+}$ on EFB with Omphalina sp. cultured in OPEFB immobilized using RBC System 


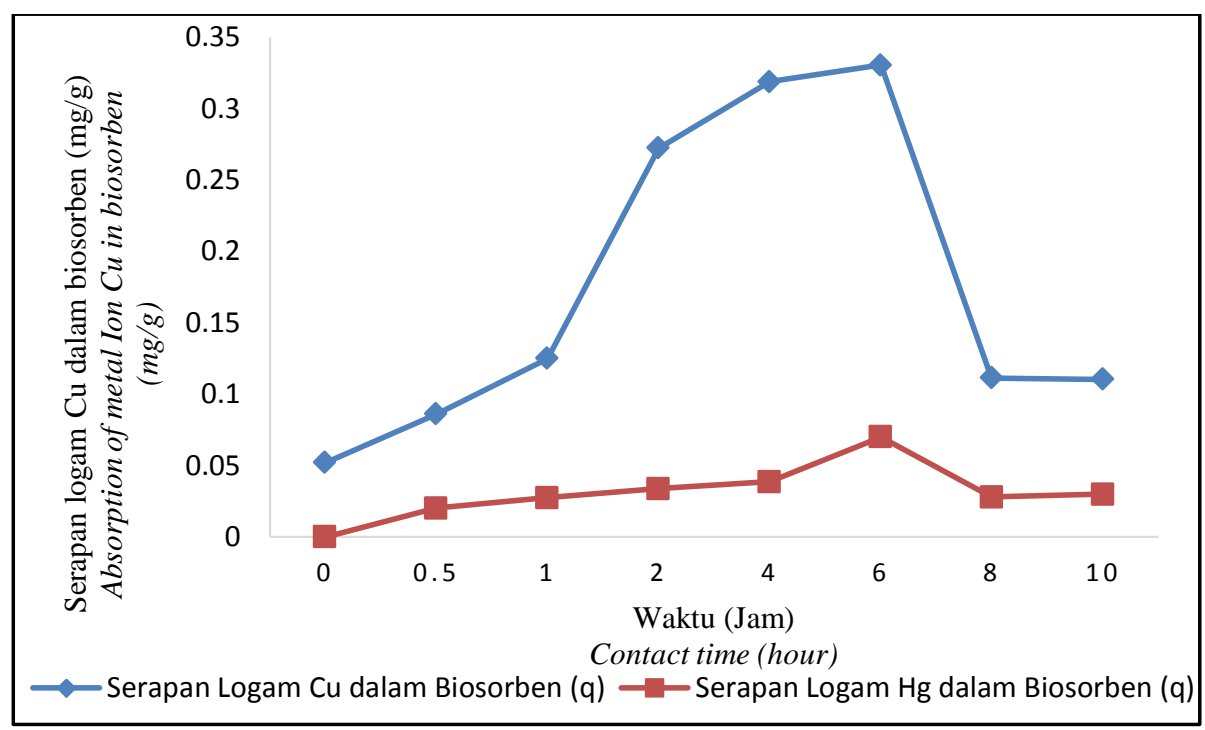

Gambar 7. Serapan Ion Logam $\mathrm{Cu}^{2+}$ dan $\mathrm{Hg}^{2+}$ dalam jamur pelapuk putih kultur Omphalina sp. pada TKKS menggunakan $\mathrm{RBC}$

Figure 7. The absorption of metal ion $\mathrm{Cu}^{2+}$ and $\mathrm{Hg}^{2+}$ in the white rot fungi Omphalina sp. cultured in EFB using RBC

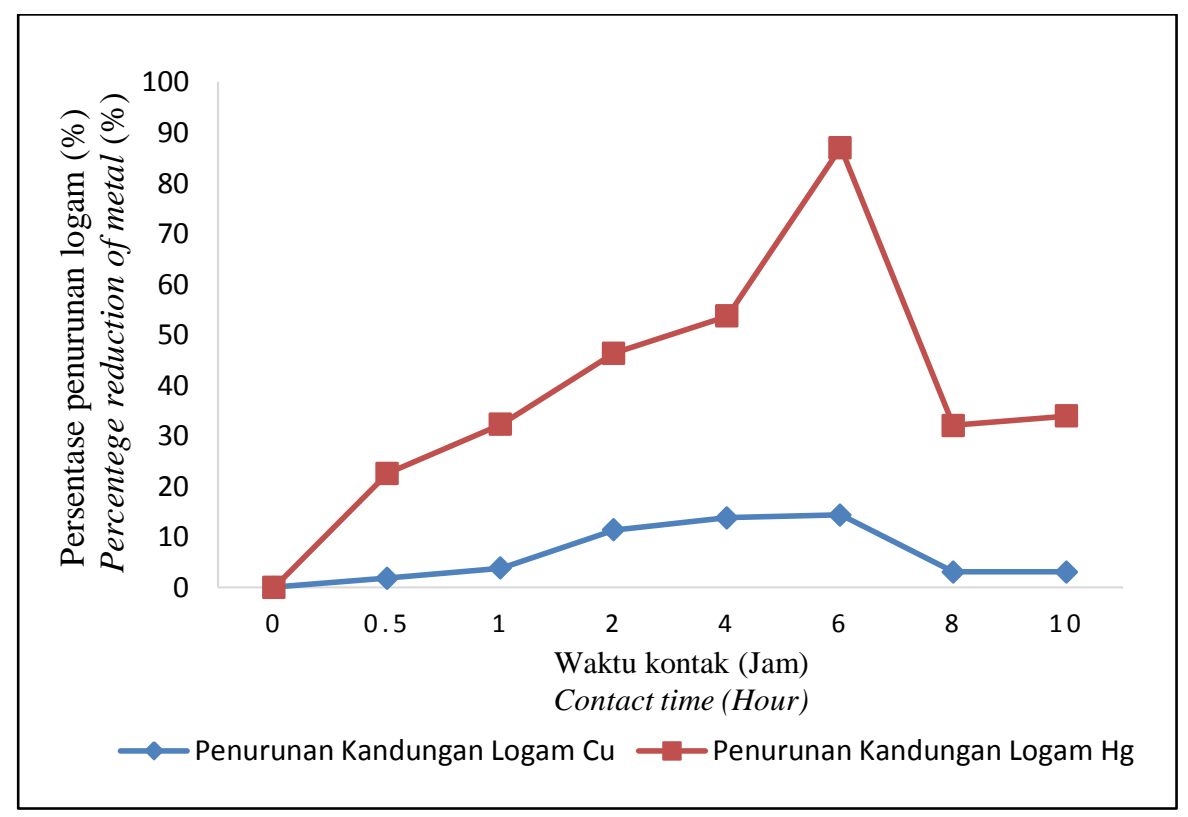

Gambar 8. Persentase penurunan ion logam $\mathrm{Cu}^{2+}$ dan $\mathrm{Hg}^{2+}$ dalam kultur Omphalina sp. pada TKKS menggunakan teknik RBC

Figure 8. Percentage reduction of metal ion $\mathrm{Cu}^{2+} \mathrm{dan}_{\mathrm{Hg}^{2+}}$ in the white rot fungi Omphalina sp. cultured in EFB immobilized using $R B C$

Serapan maksimum ( $\left.q_{\text {maks }}\right)$ Omphalina sp. pada persamaan freundlich

Serapan maksimum dihitung dengan menggunakan persamaan sorpsi Freundlich. Kapasitas maksimum penyerapan berbeda-beda, tergantung dari banyaknya biomassa dan besarnya konsentrasi larutan yang digunakan. Persamaan isoterm sorpsi Freundlich dihitung dengan mulamula menentukan persamaan linear Freundlich. Persamaan tersebut didapat dari plot grafik antara $\log X_{m} / m$ vs $\log C_{e}$ sehingga akan didapatkan persamaan liniear untuk $\mathrm{Cu}^{2+}$ adalah $\mathrm{y}=$ $0,09 x+1,8568$ (Gambar 9) dengan nilai regresi $\mathrm{R}^{2}$ sebesar 0,9468 (mendekati 1). Sedangkan pada $\mathrm{Hg}^{2+}$ persamaan linearnya adalah $\mathrm{y}=-1,0289 \mathrm{x}-$ 1,3057 (Gambar 10) dengan nilai regresi $R^{2}$ sebesar 0,9061 , nilai $\mathrm{k}$ dan $\mathrm{n}$ nya dapat dihitung dari persamaan linear tersebut (Tabel 1).

Berdasarkan perhitungan isoterm Freundlich, nilai konstanta kesetimbangan $\mathrm{n}$ untuk $\mathrm{Cu}^{2+}$ adalah $-11,11$ sedangkan untuk $\mathrm{Hg}^{2+}$ adalah -0.97 . Kedua biosorpsi logam tersebut memiliki $n<1$ yang berarti terserap secara kimia. Hal tersebut sesuai dengan dugaan awal bahwa dalam biosorpsi $\mathrm{Cu}^{2+}$ dan $\mathrm{Hg}^{2+}$ dengan Omphalina sp. imobil terjadi reaksi pertukaran ion. Kapasitas 
serapan maksimum $(\mathrm{K})$ atau $\mathrm{q}$ maks untuk $\mathrm{Cu}^{2+}$ adalah $71,911 \mathrm{mg} / \mathrm{g}$ lebih besar dibandingkan dengan serapan maksimum untuk $\mathrm{Hg}^{2+}$ yaitu 20,216 mg/g (Tabel 1). Hal tersebut dapat dipahami karena $\mathrm{Hg}^{2+}$ lebih toksik dari pada $\mathrm{Cu}^{2+}$, dan $\mathrm{Cu}^{2+}$ juga merupakan logam esensial yang antara lain berperan sebagai kofaktor enzim lakase Omphalina sp. Hasil penelitian sebelumnya diketahui bahwa Omphalina sp. mampu tumbuh dengan bagus pada kadar $\mathrm{Cu}^{2+}$ yang tinggi (100-300 mg/L), sedangkan pada $\mathrm{Hg}^{2+}$ maksimum hanya $5 \mathrm{mg} / \mathrm{L}$. Dari data percobaan menunjukkan bahwa daya sorpsi Omphalina sp. masih dibawah kapasitas maksimumnya sehingga jamur tersebut masih berpotensi untuk bisa digunakan ulang (reuse).

Jamur Omphalina sp. yang ditumbuhkan pada media TKKS menyebabkan permukaannya tidak homogen pada setiap sisi TKKS. Model persamaan Freundlich mengasumsikan bahwa terdapat lebih dari satu lapisan permukaan (multilayer) dan sisi bersifat heterogen, yaitu adanya perbedaan energi pengikat pada tiap-tiap sisi dimana proses adsorpsi di tiap-tiap sisinya mengikuti persamaan tersebut (Handayani, 2009; Kotbra, 2011). Serapan maksimum yang dihasilkan menunjukkan bahwa daya adsorpsi Omphalina sp. masih cukup tinggi terhadap logam $\mathrm{Cu}^{2+}$ dan $\mathrm{Hg}^{2+}$ sehingga jamur tersebut masih berpotensi untuk bisa digunakan ulang (Reuse).

Serapan ion logam $\mathrm{Cu}^{2+}$ mencapai 71,911 $\mathrm{mg} / \mathrm{g}$ dan serapan ion logam $\mathrm{Hg}^{2+}$ yaitu 20,216 $\mathrm{mg} / \mathrm{g}$ (Tabel 1). Hasil perhitungan isoterm sorpsi Freundlich menunjukkan serapan maksimum logam lebih tinggi $\mathrm{Cu}^{2+}$ karena konsentrasi $\mathrm{Cu}^{2+}$ yang digunakan lebih tinggi konsentrasinya dibandingkan dengan $\mathrm{Hg}^{2+}$ serta $\mathrm{Hg}^{2+}$ lebih bersifat toksik dibandingkan dengan $\mathrm{Cu}^{2+}$

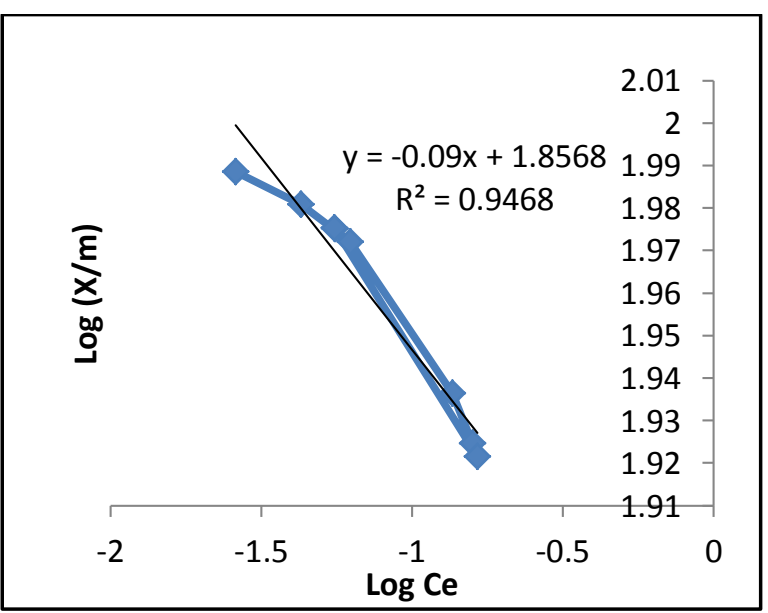

Gambar 9. Persamaan linear Freundlich pada ion logam $\mathrm{Cu}^{2+}$.

Figure 9. The linear equation of Freundlich on metal ion $\mathrm{Cu}^{2+}$. sehingga mempengaruhi daya adsorpsinya. Hal ini sesuai dengan penelitian sebelumnya bahwa Omphalina sp. mampu tumbuh dengan bagus pada kadar $\mathrm{Cu}^{2+}$ yang tinggi berkisar 100-300 ppm sedangkan pada $\mathrm{Hg}$ maksimum hanya 5 ppm.

Penggunaan ulang jamur pelapuk putih Omphalina sp. (reuse)

Biosorben harus dapat digunakan berkali-kali untuk mengurangi biaya (Suharyanto, 2014). Penggunaan ulang Omphalina sp pada larutan logam baru dilakukan sampai dua kali penggunaan dan tetap terjadi penyerapan, dilihat dari persentase penyerapan jamur Omphalina sp. (Tabel 2 dan 3). Hal ini menunjukan bahwa Omphalina sp. dapat digunakan secara berulang menggunakan limbah yang baru sehingga dapat mengefesienkan penggunakan jamur Omphalina sp dalam pengolahan limbah. Masih adanya biomassa jamur yang hidup setelah penggunaan pada siklus pertama, menandakan biosorben masih berpotensi untuk menyerap ion-ion logam. Akan tetapi tidak hanya biomassa yang masih hidup saja yang dapat digunakan sebagai biosorben untuk menyerap ion-ion logam, biomassa yang sudah matipun dapat digunakan untuk menyerap ion-ion dalam larutan (Javaid $e t$ al., 2011).

Pada penggunaaan ulang proses penyerapan terjadi penurunan karena sudah menggunakan jamur Omphalina sp. Penurunan aktivitas metabolisme dan kejenuhan dari pori-pori sel dan gugus fungsi, nilai dari persen penyerapan menunjukan Omphalina sp. masih dapat menyerap ion logam berat. Persen penyerapan ion logam $\mathrm{Hg}^{2+}$ sebesar $26,71 \%$ dan penyerapan pada ion logam $\mathrm{Cu}^{2+}$ sebesar $2,75 \%$ dapat dilihat pada Tabel 2 dan 3.

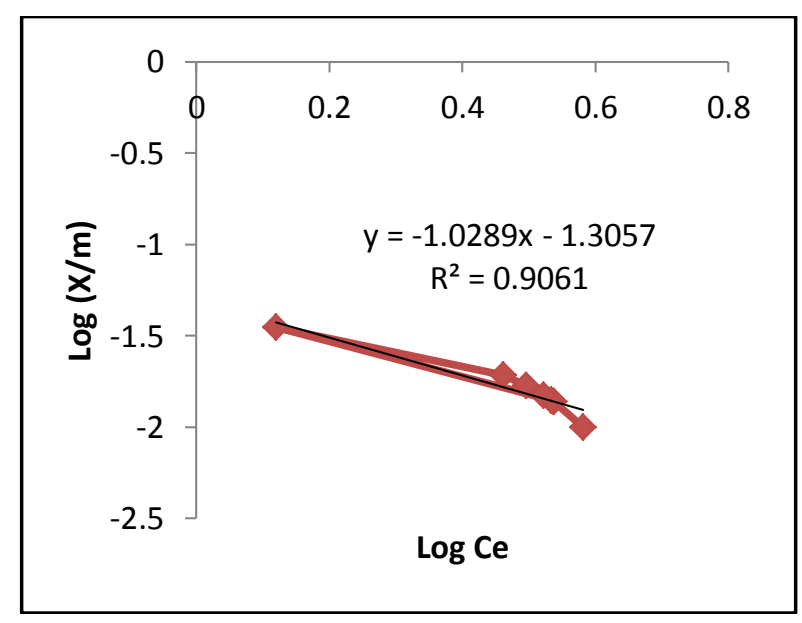

Gambar 10. Persamaan linear Freundlich pada ion logam $\mathrm{Hg}^{2+}$.

Figure 10. The linear equation of Freundlich on metal ion $\mathrm{Hg}^{2+}$. 
Tabel 1. Hasil perhitungan isoterm absorpsi Freundlich logam berat $\mathrm{Cu}^{2+}$ dan $\mathrm{Hg}^{2+}$

Tabel 1. The results of calculation adsorption isotherms Freundlich heavy metal $\mathrm{Cu}^{2+}$ and $\mathrm{Hg}^{2+}$

\begin{tabular}{ccccc}
\hline $\begin{array}{c}\text { Ion logam/ } \\
\text { Metal ion }\end{array}$ & $\mathrm{R}^{2}$ & $\begin{array}{c}\text { Persamaan Linear/ } \\
\text { Linear equation }\end{array}$ & $\begin{array}{c}\mathrm{q} \mathrm{maks} / q \\
\text { max }(m g / g)\end{array}$ & $\begin{array}{c}\text { Konstanta Freundlich/ } \\
\text { Freundlich constantan }\end{array}$ \\
\hline $\mathrm{Cu}^{2+}$ & 0.9468 & $\mathrm{y}=-0,09 \mathrm{x}+1,8568$ & 71,911 & $-11,11$ \\
$\mathrm{Hg}^{2+}$ & 0.9061 & $\mathrm{y}=-1,0289 \mathrm{x}-1,3057$ & 20,216 & $-0,97$ \\
\hline
\end{tabular}

Tabel 2. Persentase penurunan kandungan ion logam $\mathrm{Cu}^{2+}$ pada penggunaan ulang Omphalina sp.

Tabel 2. The percentage decrease content of metal ioin $\mathrm{Cu}^{2+}$ on reuse Omphalina sp.

\begin{tabular}{lccc}
\hline \multicolumn{1}{c}{$\begin{array}{c}\text { Waktu (t)/ } \\
\text { Time }\end{array}$} & $\begin{array}{c}\text { Konsentrasi awal logam/ } \\
\text { Initial concentratioin of } \\
\text { metal (Co) }\end{array}$ & $\begin{array}{c}\text { Konsentrasi akhir logam/ } \\
\text { Final concentratioin of } \\
\text { metal (Cs) }\end{array}$ & $\begin{array}{c}\text { Persentase penurunan } \\
\text { logam/ } \\
\text { Percentage decrease of } \\
\text { metal }(\alpha \mathrm{s})\end{array}$ \\
\hline $\begin{array}{l}\text { Penggunaan pertama/first } \\
\text { used }\end{array}$ & $100 \mathrm{ppm}$ & $84,06 \mathrm{ppm}$ & $15,94 \%$ \\
\begin{tabular}{l} 
Penggunaan ulang/ reuse \\
\hline
\end{tabular} & $100 \mathrm{ppm}$ & $95,70 \mathrm{ppm}$ & $4,30 \%$ \\
\hline
\end{tabular}

Tabel 3. Persentase penurunan kandungan ion logam $\mathrm{Hg}^{2+}$ pada penggunaan ulang Omphalina sp.

Tabel 3. The percentage reduction of metal content of $\mathrm{Hg}^{2+}$ ion on reuse Omphalina sp.

\begin{tabular}{lccc}
\hline \multicolumn{1}{c}{$\begin{array}{c}\text { Waktu }(\mathrm{t}) / \\
\text { Time }\end{array}$} & $\begin{array}{c}\text { Konsentrasi awal logam/ } \\
\text { Initial concentratioin of } \\
\text { metal (Co) }\end{array}$ & $\begin{array}{c}\text { Konsentrasi akhir logam/ } \\
\text { Final concentration of metal } \\
(\mathrm{Cs})\end{array}$ & $\begin{array}{c}\text { Persentase penurunan } \\
\text { logam/ }\end{array}$ \\
\hline $\begin{array}{l}\text { Percentage decrease of } \\
\text { metal }(\alpha)\end{array}$ \\
$\begin{array}{l}\text { used } \\
\text { Penggunan pertama/ first }\end{array}$ & $5 \mathrm{ppm}$ & $2,90 \mathrm{ppm}$ & $42,08 \%$ \\
\hline
\end{tabular}

Faktor yang mempengaruhi proses biosorpsi adalah konsentrasi ion logam, suhu, $\mathrm{pH}$, dan konsentrasi biomassa (Das et al., 2008). Penelitian serupa menggunakan Pleurotus ostreatus untuk menyerap logam $\mathrm{Cu}^{2+}$ terjadi penurunan konsentrasi logam yang sangat tajam pada 15-120 menit pertama. Hasil ini sejalan dengan penelitian dengan Omphalina sp. (Gambar 7) yang menunjukkan waktu serapan berlangsung cepat pada 1-2 jam pertama. Serapan berlangsung cepat pada jam pertama dan kedua karena permukaan jamur masih belum terpenuhi ion logam. Lalu dilanjutkan penyerapan lambat karena transportasi membran ion logam ke dalam sitoplasma sel atau lambatnya difusi intraseluler (Javaid et al., 2011).

Penelitian yang lainnya menggunakan Aspergillus flavus untuk biosorpsi $\mathrm{Cu}^{2+}$ memiliki waktu optimum 15-120 menit (Iskandar et al. 2011). Ikatan ion logam dipengaruhi gugus fungsional yang berada di permukaan jamur, mula-mula dengan cepat ion logam akan berikatan dengan sisi negatif dari dinding sel jamur (Say et al., 2007). Hasil ini lebih rendah daripada biosorpsi menggunakan $M$. rouxi dengan konsentrasi awal $100 \mathrm{ppm}$ dan setelah 7 jam menjadi 20 ppm (80 \%) (Victor et al. 2012). Semakin tinggi konsentrasi ion logam maka efisiensi penyerapan biomassa akan semakin rendah. Hal itu dikarenakan peningkatan jumlah ion logam semakin meningkat untuk dapat berikatan dengan biomassa dan kurangnya sisi kompleksitas dari biomassa untuk mengikat seluruh ion logam (Ranjusha et al., 2010).

Biosorpsi menggunakan rotary biological contactor

Biosorpsi larutan logam menggunakan teknik RBC memiliki keefektifan yang baik karena Omphalina sp merupakan organisme aerob (Suharyanto et al., 2014) sehingga untuk kelangsungan hidupnya Omphalina sp memerlukan oksigen. Metode RBC membuat oksigen lebih banyak dapat terserap oleh Omphalina sp. sehingga Omphalina sp masih dapat hidup dan diharapkan biomassa bertambah banyak. Semakin banyak biomassa maka serapan logam akan semakin optimum (Victor et al., 2012).

Mahluk hidup memiliki perbedaan dalam bertahan hidup di lingkungan toksik. Omphalina sp. mampu bertahan hidup pada lingkungan yang tercemar oleh limbah tertentu misalnya, pada konsentrasi $\mathrm{Cu}^{2+} 300 \mathrm{ppm}$ dan $\mathrm{Hg}^{2+} 5 \mathrm{ppm}$ Omphalina masih dapat hidup (Dimawarnita $e t$ al., 2015). Hal itu menandakan pada konsentrasi 
$\mathrm{Cu}^{2+} 300$ ppm dan $\mathrm{Hg}^{2+} 5$ ppm, belum mempengaruhi metabolisme dari Omphalina sp. Jamur merupakan organisme aerob (Suprihatin et $\mathrm{pH}$ rendah (berkisar antara 4-9), media yang tinggi karbohidrat dan selulosa, pada suhu optimum $39{ }^{\circ} \mathrm{C}$, dan kelembaban udara yang cukup berkisar antara 70-80\% (Suprihatin 2009, Soeprijanto et al. 2007).

\section{Kesimpulan}

Teknik Rotary Biological Contactor (RBC) dapat digunakan untuk biosorpsi ion logam $\mathrm{Cu}^{2+}$ dan $\mathrm{Hg}^{2+}$ dengan kultur Omphalina sp. pada TKKS. Penyerapan tertinggi ion $\mathrm{Cu}^{2+}$ sebesar $0,3304 \mathrm{mg} / \mathrm{g}$ dan $\mathrm{Hg}^{2+}$ sebesar $0,074 \mathrm{mg} / \mathrm{g}$ selama 6 jam. Penentuan kapasitas adsorpsi Omphalina sp. terhadap larutan $\mathrm{Cu}^{2+}$ dan $\mathrm{Hg}^{2+}$ dengan menggunakan persamaan adsorpsi Freundlich dengan daya adsorpsi maksimumnya untuk $\mathrm{Cu}^{2+}$ sebesar $71,911 \mathrm{mg} / \mathrm{g}$ dan untuk $\mathrm{Hg}^{2+}$ sebesar $20,216 \mathrm{mg} / \mathrm{g}$. Biosorben Omphalina sp. dapat digunakan ulang dalam proses biosorpsi dengan persentase penurunan $\mathrm{Cu}^{2+}$ sebesar $4,30 \%$ dan $\mathrm{Hg}^{2+}$ sebesar $27,80 \%$.

\section{UCAPAN TERIMA KASIH}

Penelitian ini terlaksana berkat bantuan dana dari program Kerjasama Kemitraan Penelitian dan Pengembangan Pertanian Nasional (KKP3N), Badan Penelitian dan Pengembangan Pertanian, Kementerian Pertanian RI dengan kontrak Nomor: 44.87/HM.230/I.1/3/2015 Tanggal 5 Maret 2015. Peneliti mengucapkan terima kasih atas kepercayaan Badan Penelitian dan Pengembangan Pertanian mendanai penelitian ini.

\section{Daftar Pustaka}

Ahluwalia SS \& Goyal D (2007). Microbial and plant derived biomass for removal of heavy metals from waste water. Bioresourch Technol 98, 2243-2257.

Bordelius P (1987). Stress induced metabolism in plant cell cultures. In: Pais MSS, Mavutina F, Novias JM, NATO ASI Series (eds), Plant Cell Biotechnology. Springer-Verlag. Pp.195210.

Busuioc G \& Carmen CE (2013). Responce of four russula species under copper sulphate and lead acetate treatments. Not Bot Horti Agrobo 41(2), 538-545.

Chergui A, MZ Bakhti, A Chahboub, S Haddoum, A Selatnia \& GA Unter (2007). Simultaneus biosorption of $\mathrm{Cu}^{2+}, \mathrm{Zn}^{2+}$, and $\mathrm{Cr}^{6+}$, from aqueus solution by Streptomyces risomus. Desalination. Elsevier. 206, 179-184.

Das N (2005). Heavy metals biosorption by mushrooms. Natural product radiance. p 454458. al., 2009), sehingga aktivitas biologisnya juga dipengaruhi oleh adanya oksigen dalam lingkungan. Omphalina sp. dapat tumbuh pada

Das N, R Vimala \& P Karthika (2008). Biosorption of heavy metals-An overview. Indian journal of Biotechnology 7, 159-169.

Dimawarnita F, Suharyanto, Tri Panji, Ahmad Z \& Nur R (2015). Biosorpsi ion tembaga dalam limbah tailing menggunakan jamur pelapuk putih amobil. Menara Perkebunan 83(1), 2736.

Fu F \& Wang Q (2011). Removal of heavy metal ions from wastewaters: A review. Journal of Envronmental Management 92, 407-418.

García M, Alonso J \& Melgar M (2005). Agaricus macrosporus as a potential bioremediation agent for substrates contaminated with heavy metals. J Chem Technol Biotechnol 80, 325330.

Handayani M \& Eko S (2009). Uji persamaan langmuir dan freundlich pada penyerapan limbah chrom (VI) oleh zeolit. In: Prosiding Seminar Nasional Sains dan teknologi Nuklir. Bandung, 3 Juni 2009, halaman: 130-136.

Iskandar NY, Nur Ain I, Moh Zainudin \& Soon GT (2011). Tolerance and biosorption of copper $(\mathrm{Cu})$ and lead $(\mathrm{Pb})$ by filamentous fungi isolated from freshwater ecosystem. Journal of Environmental Sciences 23(5), 824830.

Javaid A, Badar T \& Aslam N (2011). Removal of $\mathrm{Pb}(\mathrm{II}), \mathrm{Cu}(\mathrm{II}) \& \mathrm{Cd}(\mathrm{II})$ from aqueos solution by some fungi and natural adsorbents in single \& multiple metal systems. Pak J Bot. 43, 2997-3000.

Kotrba P (2011). Microbial biosorption of metals-General Introduction. In Microbial biosorption of metals (pp. 1-6). Springer Netherlands.

Lim on-Pacheco J \& ME Gonsebatt (2009). The role of antioxidants and antioxidant- related enzymes in protective responses to environmentally induced oxidative stress. Mutation Research. Genetic Toxicology and Environmental Mutagenesis. 674(1-2), 137147.

Mawardi (2007). Kajian biosorpsi ion-ion logam berat oleh biomassa alga hijau Spirogyra subsalsa. Program Studi Ilmu Kimia [Disertasi] Depok, Universitas Indonesia.

Milovanović I, I Brčeski, M Stajić, A Korać, J Vukojević \& A Knežević (2014). Potential of Pleurotus ostreatus mycelium for selenium absorption. The Scientific World Journal. 2014 (1), 1-8.

Muslimah S \& Kuswytasari ND (2013). Potensi basidiomycetes koleksi biologi ITS sebagai 
agen biodekolorisasi zat warna RBBR. Jurnal Sains dan Seni Pomits 2 (1), 2337-3520.

Patil, M.S and Kulkarni M.V. 2016. Investigations on biosorption of colorants in distillery spent wash by nonviable aspergillus oryzae MTCC 7691: kinetics and Isotherm studies. International Journal of Scientific \& Engineering Research, 7(1) 925-935.

Ranjusha VP, Reena P, Kapil K, MG Dastidar \& TR Sreekrishnan (2010). Biosorption of remazol black B dye (azo dye) by the growing Aspergillus flavus. Journal of Environmental Science and Health 45(10), 1256-1263.

Say R, Yilmaz N \& Denizli A (2007). Biosorption of cadmium, lead, mercury, and arsenic ions by the fungus Penicillium purpurogenum. Separation Science and Technology. 38(9), 2039-2053.

Soeprijanto, Aryanto B \& Fabella R (2007). Biosorpsi ion logam berat $\mathrm{Cu}$ (II) dalam larutan menggunakan biomassa Phanerochaete chrysoporium. Jurnal Ilmiah Sains dan Teknologi. 6(1), 61-67.
Suharyanto (2014). Teknik penanganan limbah tailing menggunakan Omphalina sp. dengan berbagai metode (rotary biological contactor, packed bed, continue). Bogor: Laporan internal penelitian KKP3N.

Suprihatin \& Erik A (2009). Biosorpsi logam Cu (II) dan $\mathrm{Cr}$ (VI) pada limbah elektroplating dengan menggunakan biomassa Phanerochaete chrysosporium. Jurnal Teknik Kimia. 4(1), 250-254.

Svoboda L, Zimmermannova $\mathrm{K}$ \& Kalač $\mathrm{P}$ (2000). Concentrations of mercury, cadmium, lead and copper in fruiting bodies of edible mushrooms in an emission area of a copper smelter and a mercury smelter. Sci Total Environ 246,61-67.

Victor M, Juan F, Maria ET, Ismail AR (2012). Biosorption of mercury (II) from aqueous solutionsonto fungal biomass. Bioinorganic Chemistry and Applications. 3 (1), 1-5.

Zabowski D, Zasoski RJ, Littke W, Ammirati J (1990). Metal content of fungal sporocarps from urban, rural and sludge-treated sites. $J$ Environ Qual 19(3), 372-377. 